\title{
Yerli ve yabancı yumurtacı hibrit sürülerde yumurta ağırlığının zamana bağlı değişiminin karşılaștırılması ve modellenmesi
}

\author{
İsmail TÜRKER ${ }^{1}$, Doğan NARÍNÇ², Sezai ALKAN¹ \\ 10rdu Üniversitesi Ziraat Fakültesi Zootekni Bölümü, ORDU \\ ${ }^{2}$ Namık Kemal Üniversitesi Veteriner Fakültesi, Zootekni ve Hayvan Besleme Bölümü, TEKİRDAĞ
}

Alınış tarihi: 26 Eylül 2017, Kabul tarihi: 30 Kasım 2017

Sorumlu yazar: Sezai ALKAN, e-posta:sezaialkan61@gmail.com

Öz

$\mathrm{Bu}$ çalışmanın amacı yerli hibrit Atak-S ve yabancı hibrit Lohmann Brown sürülerinde 24-80 haftalar arasında dörder haftalık aralıklarla ölçülen yumurta ağırlıkları bakımından iki genotipin karşılaştırılması ve yumurta ağırlıklarının zamana bağlı değişiminin modellenmesidir. $\mathrm{Bu}$ amaçla genotiplerin karşılaştırılmasında çok değişkenli istatistiksel yöntemlerden profil analizi kullanılmıș olup yumurta ağırlıklarının zamana bağlı değișimlerinin modellenmesi için eğri tahmin yöntemleri ve doğrusal olmayan regresyon modelleri kullanılmıștır. Profil analizi sonucunda HotellingLawley Trace test istatistiğine göre Atak-S ve Lohmann Brown genotiplerinin haftalara göre yumurta ağırlı değerleri arasında fark bulunmamıștır $\quad(\mathrm{P}>0.05)$ Haftalı yumurta ağırlıklarındaki varyasyon katsayıları (\%) bakımından Atak-S için saptanan değerlerin daha düşük ve daha dar bir aralıkta olduğu (\%5.23\%8.59), buna karşıllk Lohmann Brown genotipine ait değerlerin hem daha yüksek hem de daha geniş bir aralıkta olduğu (\%4.16-\%9.80) belirlenmiştir. Doğrusal, Kuadratik, Kübik, Gompertz, Lojistik ve Von Bertalanffy modelleri ile gerçekleştirilen analizler sonucunda hem Atak-S hem de Lohmann Brown tavuklarının haftalık yumurta ağırlıkları için en yüksek belirleme katsayıları (sırasıyla 0.9995 ve 0.9995) ve en düşük hata kareler ortalaması değerleri (sırasıyla 2.0464 ve 2.4455 ) Gompertz modelinden elde edilmiştir. Sonuç olarak Atak-S ve Lohmann Brown sürülerinde 24-80 haftalar arasında dörder haftalık olarak ölçülen yumurta ağırlıkları bakımından iki genotip arasında farklılı bulunmamış olması, aynı zamanda yumurta ağırlığındaki bir örneklilik bakımından Atak-S genotipinin daha iyi sonuçlar vermiş olması ülke ekonomisi açısından önemli bulunmuştur.

Anahtar kelimeler: Atak-S, yumurta ağırlığı, profil analizi, bir örneklilik, eğri tahmini

Comparison and modeling of time dependent changes of egg weight in native and foreign layer hybrids

\section{Abstract}

The aim of this study is to compare the two genotypes (Native hybrid Atak-S and the foreign hybrid Lohmann Brown) in terms of egg weights measured at intervals of four weeks between the ages of 24-80 weeks, and to model the timedependent changes of egg weights. For this purpose, the Profile Analysis Tecnique of multivariate statistical methods was used to compare genotypes. Curve estimation methods and nonlinear regression models were used to model time-dependent changes in egg weights. As a result of the Profile Analysis, according to Hotelling-Lawley Trace test statistic, there was no difference between egg weight values of Atak-S and Lohmann Brown genotypes ( $\mathrm{P}>0.05)$. In terms of variation coefficients (\%) of weekly egg weights, the values of the Atak-S were lower and narrower $(5.23 \%-8.59 \%)$ whereas the values of Lohmann Brown genotype were higher and wider (4.16-9.80\%). Analysis results of linear, quadratic, cubic, Gompertz, Logistic and Von Bertalanffy models showed that the highest determination coefficient (0.9995 and 0.9995) and the lowest mean 
square error values $(2.0464$ and 2.4455 respectively) of Gompertz model for weekly egg weights of both Atak-S and Lohmann Brown chickens. As a result, there was no difference between the two genotypes (Native hybrid Atak-S and the foreign hybrid Lohmann Brown) in terms of weekly egg weights between 24 and 80 weeks, while Atak-S genotype showed better results in terms of egg weight uniformity has been found to be important for national economy.

Key words: Atak-S, egg weight, profile analysis, uniformity, curve estimation

\section{Giriş}

Dünya nüfusunun 2050 yllına kadar 10 milyar seviyesine çıkacağı öngörülmekte ve bu artışın önemli kısmının Avrupa ve Amerika kıtalarının dışında gerçekleşeceği tahmin edilmektedir (Anonim, 2014). Önümüzdeki 40 yılda dünya nüfusunun $\% 70$ 'inden fazlasının kentlerde yaşayacağı ve insanoğlunun son 8000 yılda tükettiği gıda miktarını bu süre içerisinde tüketeceği global kaynaklar tarafindan tahmin edilmektedir. Yeterli ve dengeli beslenme konusu artan dünya nüfusuyla birlikte insanoğlunun en önemli sorunudur. Türkiye'de beslenme alışkanlıkları dikkate alındığında hayvansal gıda tüketiminin yüksek olması beklenirken, bu beklentinin aksine et ve diğer hayvansal gıdaların tüketimi bir hayli düşük düzeylerdedir. Bireysel günlük hayvansal protein tüketimi gelişmiș ülkelerin yaklaşık üçte biri düzeyindeyken, kiși başına düşen bitkisel protein tüketimi gelişmiş ülkelerin yaklaşık iki katı seviyesindedir. Bu dengesizliğin giderilmesinde akla gelen ilk seçenek kanatlı hayvan ürünleridir. Yumurta gida maddesi olarak dünyanın her yerinde sevilerek tüketilen, besleyici değeri yüksek bir hayvansal protein kaynağıdır. Esansiyel amino asitler, esansiyel yağ asitleri, mineraller, yağda ve suda çözünen vitaminler (C vitamini hariç) bakımından besin deposu olarak kabul edilen tavuk yumurtasının, insanlarda kan kolesterolünü etkilemediği bilimsel çalışmalarda bildirilmiştir (Aydın ve ark., 2014). Besleyici değerinin yanında uygun fiyatı, tüketim kolaylığı ve çeşitliliği gibi faktörler de yumurta tüketimini etkilemektedir. 58$60 \mathrm{~g}$ ağırlıkta bir yumurta, içerdiği besin maddeleri bakımından ortalama olarak $90 \mathrm{~g}$ et ve $160 \mathrm{~g}$ süte denk gelmektedir (Karakaya ve ark., 2014). Türkiye'de yumurta üretimi 2000 yılında 100 adet/kişi iken bu rakam 2016 yılı itibarı ile 223 adet/kiși seviyesine yükselmiştir. Bunun yanında 2015 yılı verilerine göre Türkiye'de 93751470 adet yumurta tavuğu bulunmakta olup bu üretimi sağlayabilmek üzere yurtdışından 1091234 adet damızlık civciv ithalatı yapılmıştır (Kamanlı ve ark., 2016). Tüm dünyada olduğu gibi ülkemizde de uzun yıllardan beri yurtdışı kaynaklı hibritler üretimde yaygın olarak kullanılmaktadır. Hibrit materyallerin yurt dışından ithal edilmesi ülke tavukçuluğuna canlılık getirmiş olsa bile daha önce gözlenmemiş bazı tavuk hastalıklarının ortaya çıkması ve damızlık temininde tamamen dışa bağımlılık gibi sakıncaları yaratmıştır (Erensayın, 2000). Global pazarda geniş ölçekli hibrit üretimi yapan az sayıda şirket bulunmaktadır. Bunun yanında Kore, Polonya ve Fransa gibi ülkeler de kendi iç pazarlarına yönelik hibrit ebeveynleri geliştirmişlerdir. Türkiye de 1995 yllında Kanada'dan ithal edilen saf hatların geliştirilmesiyle Atak, Atak-S ve Atabey olarak isimlendirilen üç hibrit genotip geliştirmiştir. Tavukçuluk Araştırma Enstitüsü'nde bulunan damızlık materyal ile günümüzde ülkenin yumurta tavuğu hibriti ihtiyacının \% 2.5'lik kısmı karşılanabilmektedir. Söz konusu kurumda gerçekleştirilen sslah uygulamaları ile hibrit genotiplerin özellikle canlı ağırlık, yem tüketimi, yumurta kalitesi gibi özelliklerinin yurtdışı kaynaklı muadilleriyle rekabet edebilecek seviyelere çıkarılmasına çalışılmaktadır.

Hibrit genotiplerde yaş ve canlı ağırlık ile doğrudan ilişkili olan ve yumurta kalite özelliklerinden biri olarak kabul edilen yumurta ağırlığı da ticari üretim üzerinde oldukça etkilidir. Tavuğun yaşı ile ilgili olarak yumurtada görülen en belirgin değișimlerden birisi de ağırlıktaki artıştır. Bununla birlikte sarı ağırlığı, ak ağırlığı, kabuk ağırlığı ile sarı oranı da yaşa bağlı olarak artmakta fakat ak ve kabuk oransal olarak azalmaktadır (Förster and Flock 1997; Pingel and Jeroch 1997). Tavuk yaşının artışıyla birlikte kabuk oluşturma yeteneği azalmakta böylece yumurtlama döneminin sonuna doğru üretilen yumurta kabuğu daha ince ve zayıf hale gelmektedir. Böylece sofralık olarak pazarlanabilir yumurta sayısı azalmaktadır. Ticari hibrit genotiplerin yumurta ağırlıklarını konu alan çalışmaların çoğunda belirli haftalardaki fenotipik veriler kullanılmış olup genellikle de çevresel manipülasyonların yumurta ağırlığı üzerine etkisi konu edilmiştir. Oysa yumurta ağırlığı eşeysel olgunluk yaşından itibaren verim dönemi sonuna kadar değişken bir eğilim izlemektedir ve yumurta ağırlığının zamana bağlı değişiminin incelenmesi gerekmektedir. 
Yumurta ağırlı̆̆ının zamana bağlı değişiminin ortaya konulması konusunda sınırlı sayıda çalışma gerçekleştirilmiş olup söz konusu biyolojik olgunun matematiksel modeller kullanılarak açıklanması konusunda ise literatürde herhangi bir çalışmaya rastlanılmamıștır. Bu çalıșmanın amacı yerli hibrit Atak-S ve yabancl hibrit Lohmann Brown sürülerinde 24-80 haftalar arasında dörder haftalık olarak ölçülen yumurta ağırlıkları bakımından iki genotipin karşılaştırılması ve yumurta ağırlıklarının zamana bağlı değișiminin modellenmesidir. $\mathrm{Bu}$ amaçla genotiplerin karşılaştırılmasında çok değişkenli istatistiksel yöntemlerden profil analizi kullanılmış olup yumurta ağırlıklarının zamana bağlı değişimlerinin modellenmesi için eğri tahmin yöntemleri ve doğrusal olmayan regresyon modelleri kullanılmıştır.

\section{Materyal ve Yöntem}

Araştırmanın materyalini Tavukçuluk Araştırma Enstitüsü tarafindan geliştirilen kahverengi yumurtacı tavuk olan Atak-S ile yabancı kahverengi yumurtacı ticari hibrit oluşturmuştur. Genotipler 1. Grup: Atak-S; 2. Grup: Lohmann Brown hibrit olmak üzere iki gruba ayrılmıştır. Her bir grupta 150 adet olmak üzere toplam 300 adet tavuk kullanılmıştır. Araştırma 3 tekerrürlü olarak yürütülmüştür. Her bir tekerrürde 50 adet tavuk bulundurulmuştur. Her bir tavuk için kümes içinde $0.2 \mathrm{~m}^{2}$, kümes dışında ise $4 \mathrm{~m}^{2}$ yeşil gezinme alanı sağlanmıştır. Yeşil alanın bitki örtüsü ağırlıklı olarak ak üçgül (Trifolium

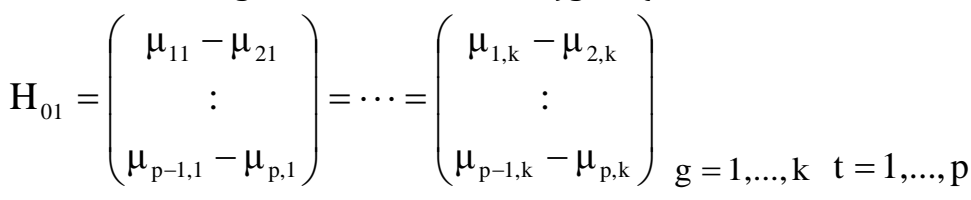

şeklinde gösterilebilir (Sristava, 1987). Eşitliklerde "k" bağımsız değişkenin içerdiği grup sayısı, "p" ise zaman noktalarını ifade etmektedir. Paralelliğin sınanmasında çok değişkenli test istatistiklerinden Hotelling-Lawley Trace kullanılmıştır (Davis, 2002).

\section{Eğri tahmini}

Yumurta ağırlıklarının zamana bağlı değișiminin eğri tahmini için doğrusal, kuadratik ve kübik regresyon modelleri kullanılmıştır. $\mathrm{Bu}$ modellerin ifadeleri sirasıyla şu şekildedir; $Y=a+\beta_{0} t, \quad Y=a+\beta_{0} t+\beta_{1} t^{2}$, $Y=a+\beta_{0} t+\beta_{1} t^{2}+\beta_{2} t^{3}$. Burada $Y$, herhangi bir $t$. zaman noktasındaki yumurta ağırlığı; a, model sabiti; $\beta_{0}, \beta_{1}$ ve $\beta_{2}$ ise eğrinin biçimlenmesini karakterize eden model parametreleridir (Narinç ve ark., 2014/a). Modellere ait eğri parametreleri, belirleme repens) çayır üçgülü (Trifolium pretense), ingiliz çimi (Lolium perenne), kırmızı yumak (Festuca rubra), ısırgan (Urtica dioica), koyun gözü (Bellis perennis) ve çuha çiçeği (Primula spp.)' den oluşmuştur. Tavukların beslenmesinde \%18 ham protein ve 2800 $\mathrm{kkal} / \mathrm{kg}$ metabolik enerjili yem kullanılmış olup su serbest olarak verilmiştir.

\section{Profil analizi}

Yumurta ağırlıklarının zaman noktalarında ölçülen değerleri bakımından Atak-S ve Lohmann Brown sürüleri arasındaki farklılığın belirlenmesinde profil analizi tekniğinden yararlanılmıştır. Profil analizi çok değişkenli varyans analizinin (MANOVA) özel bir halidir (Mendeş ve ark., 2007; Eyduran ve ark., 2008; Ohaegbulem and Nwobi, 2009). Söz konusu yöntem, aynı deneme ünitesinden farklı özelliklere ait ölçüm alındığında ya da aynı deneme ünitesinden bir özelliğe ait farklı zaman noktalarında ölçüm alındığında bağımsız değişkenin seviyelerine ilişkin profillerin karşılaştırılmasında kullanılmaktadır. Profil analizi ile temel olarak üç hipotez test edilmektedir. Bunlar, profillerin paralellik testi $\left(\mathrm{H}_{01}\right)$, örtüşmelerine $\left(\mathrm{H}_{02}\right)$ ve seviyelerine $\left(\mathrm{H}_{03}\right)$ ilişkin testlerdir. Profil analizinde üzerinde en çok durulan test paralellik testidir ve diğer testler paralellik koşulunun sağlanmasına bağlıdır. Bağımlı değişkene ait ölçümlerin birbirini izleyen noktaları arasındaki farklar, bağımsız değişkenin tüm seviyelerinde aynı ise grupların profilleri paraleldir. Paralellik testine ilişkin sıfır hipotezi

katsayıları $\left(\mathrm{R}^{2}\right)$ ve hata kareler ortalamaları belirlenmiştir (Narinç ve ark., 2010/a).

\section{Doğrusal olmayan regresyon modelleri}

Yumurta ağırlıklarının zamana bağlı değişiminin modellenmesi amacıyla yaygın kullanılan doğrusal olmayan regresyon modellerinden Gompertz, Logistic, Von Bertalanffy fonksiyonları kullanılmıştır. Söz konusu fonksiyonların ifadeleri sırasıyla şu şekildedir;

$\beta_{0} e^{-\beta_{1} e^{-\beta_{2} t}}, \quad \beta_{0} /\left(1+\beta_{1} e^{-\beta_{2} t}\right), \quad \beta_{0}\left(1-\beta_{1} e^{-\beta_{2} t}\right)^{3}$. Tüm modellerde $\beta_{-} 0$ parametresi asimptotik ağırlığı ifade etmekte, diğer tüm parametreler ise modelin şekliyle ve anlık ağırlık artışı ile ilgili model sabitleri olarak tanımlanmaktadır (Narinç ve ark., 2010/b). 


\section{Bulgular}

Atak-S ve Lohmann Brown hibritlerinin haftalara göre yumurta ağırlıklarına ilişkin tanımlayıcı istatistikler Çizelge 1'de sunulmuştur. Her iki genotipin de yumurta ağırlıkları öngörüldüğü şekilde zamana bağlı olarak artış göstermekte olup 24 haftalık yaşta Atak-S tavuk yumurtaları ortalama 50.20 g ağırlığa sahipken deneme sonu olan 80 haftalık yaşta bu ortalama $66.92 \mathrm{~g}$ olarak ölçülmüştür. Benzer şekilde Lohmann Brown genotipinin yumurta ağırlı ortalamaları da 24 haftalık yaşta $50.39 \mathrm{~g}$ bulunurken, 80 haftalık yaşta bu ortalama 69.64 g olarak ölçülmüştür. Atak-S ve Lohmann Brown hibritlerinin haftalara göre yumurta ağırlıklarına ilişkin grafiksel gösterim Şekil 1 'de sunulmuştur. İki genotipin haftalara göre yumurta ağırlıklarına ilişkin fark olup olmadığının test edildiği profil analizi sonuçları Çizelge 2'de sunulmuştur. Çizelge 2 incelendiğinde sadece 28-32,
36-40 ve 40-44 haftalık zaman dilimleri bakımından genotiplerin yumurta ağırlık değişimleri arasında istatistiksel olarak önemli farklılıklar bulunmuş olup $(\mathrm{P}<0.05)$, tüm zaman dilimini kapsayan MANOVA test istatistiğine (Hotelling-Lawley Trace) göre Atak$S$ ve Lohmann Brown hibritlerinin haftalara göre yumurta ağırlı değişimleri arasında fark bulunmamıştır $(\mathrm{P}>0.05)$.

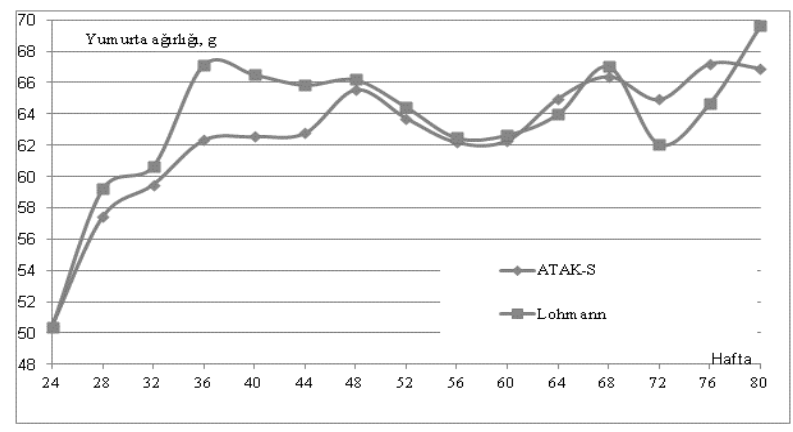

Şekil 1. Atak-S ve Lohmann Brown hibritlerinin haftalara göre yumurta ağırlıklarının değișimi.

Çizelge 1. Atak-S ve Lohmann Brown hibritlerinin haftalara göre yumurta ağırlıklarına ilişkin tanımlayıcı değerler

\begin{tabular}{|c|c|c|c|c|c|c|c|}
\hline Hafta & $\mathrm{N}$ & Ortalama & $\begin{array}{l}\text { Standart } \\
\text { sapma }\end{array}$ & $\begin{array}{c}\text { Standart } \\
\text { hata }\end{array}$ & $\begin{array}{c}\text { Varyasyon } \\
\text { katsayıs (\%) }\end{array}$ & $\begin{array}{c}\text { En küçük } \\
\text { gözlem }\end{array}$ & $\begin{array}{c}\text { En büyük } \\
\text { gözlem }\end{array}$ \\
\hline \multicolumn{8}{|c|}{ Atak-S } \\
\hline 24 & 32 & 50.20 & 3.71 & 0.66 & 7.38 & 41.89 & 59.46 \\
\hline 28 & 30 & 57.41 & 3.00 & 0.55 & 5.23 & 50.13 & 63.00 \\
\hline 32 & 20 & 59.48 & 4.25 & 0.95 & 7.14 & 52.48 & 68.70 \\
\hline 36 & 24 & 62.32 & 4.21 & 0.86 & 6.75 & 56.31 & 73.39 \\
\hline 40 & 20 & 63.06 & 4.50 & 1.01 & 7.14 & 53.00 & 70.93 \\
\hline 44 & 21 & 62.77 & 5.39 & 1.18 & 8.59 & 54.43 & 76.29 \\
\hline 48 & 21 & 65.54 & 3.63 & 0.79 & 5.53 & 59.24 & 72.10 \\
\hline 52 & 20 & 63.72 & 4.49 & 1.00 & 7.04 & 56.13 & 72.95 \\
\hline 56 & 20 & 62.17 & 4.80 & 1.07 & 7.72 & 52.80 & 71.06 \\
\hline 60 & 20 & 62.30 & 3.64 & 0.81 & 5.84 & 55.24 & 67.30 \\
\hline 64 & 20 & 64.99 & 3.90 & 0.87 & 5.99 & 58.78 & 74.05 \\
\hline 68 & 20 & 66.39 & 4.91 & 1.10 & 7.40 & 58.65 & 76.64 \\
\hline 72 & 20 & 64.92 & 4.72 & 1.06 & 7.27 & 54.92 & 72.67 \\
\hline 76 & 20 & 67.20 & 4.46 & 1.00 & 6.63 & 57.43 & 73.78 \\
\hline 80 & 20 & 66.92 & 5.08 & 1.14 & 7.58 & 57.45 & 76.97 \\
\hline \multicolumn{8}{|c|}{ Lohmann Brown } \\
\hline 24 & 31 & 50.39 & 3.82 & 0.69 & 7.58 & 41.55 & 58.18 \\
\hline 28 & 30 & 59.20 & 3.17 & 0.58 & 5.35 & 52.81 & 64.44 \\
\hline 32 & 20 & 60.66 & 3.28 & 0.73 & 5.40 & 54.41 & 69.22 \\
\hline 36 & 24 & 67.15 & 3.92 & 0.80 & 5.83 & 61.13 & 78.95 \\
\hline 40 & 20 & 66.52 & 4.28 & 0.96 & 6.43 & 58.17 & 75.22 \\
\hline 44 & 20 & 65.85 & 4.28 & 0.96 & 6.50 & 57.30 & 73.43 \\
\hline 48 & 20 & 66.18 & 4.94 & 1.10 & 7.46 & 56.66 & 76.22 \\
\hline 52 & 20 & 64.44 & 4.20 & 0.94 & 6.53 & 57.51 & 74.23 \\
\hline 56 & 20 & 62.47 & 4.24 & 0.95 & 6.78 & 55.90 & 70.66 \\
\hline 60 & 19 & 62.65 & 4.64 & 1.06 & 7.41 & 54.49 & 72.28 \\
\hline 64 & 20 & 63.99 & 3.71 & 0.83 & 5.79 & 57.83 & 70.66 \\
\hline 68 & 20 & 67.03 & 6.57 & 1.47 & 9.80 & 57.76 & 78.88 \\
\hline 72 & 16 & 63.14 & 2.63 & 0.66 & 4.16 & 60.22 & 69.81 \\
\hline 76 & 20 & 64.68 & 4.00 & 0.89 & 6.19 & 56.44 & 72.79 \\
\hline 80 & 20 & 69.64 & 5.72 & 1.28 & 8.21 & 60.03 & 77.75 \\
\hline
\end{tabular}


Çizelge 2. Atak-S ve Lohmann Brown hibritlerinin haftalara göre yumurta ağırlıklarına ilişkin profil analizi sonuçları

\begin{tabular}{cc}
\hline Zaman aralıkları (hafta) & P değeri \\
\hline $24-28$ & 0.5089 \\
$28-32$ & $0.0330^{*}$ \\
$32-36$ & 0.1412 \\
$36-40$ & $0.0441^{*}$ \\
$40-44$ & $0.0223^{*}$ \\
$44-48$ & 0.7268 \\
$48-52$ & 0.7758 \\
$52-56$ & 0.0797 \\
$56-60$ & 0.3527 \\
$60-64$ & 0.0693 \\
$64-68$ & 0.3417 \\
$68-72$ & 0.1524 \\
$72-76$ & 0.0994 \\
$76-80$ & 0.1316 \\
\hline
\end{tabular}

Yumurta ağırlıklarının zamana bağlı değișiminin eğri tahmini ve doğrusal olmayan regresyon modelleri ile gerçekleştirilen parametre tahminlerine ilişkin değerler ve söz konusu modellere ait belirleme katsayıları $\left(\mathrm{R}^{2}\right)$ ile hata kareler ortalamaları (HKO) Çizelge 3'te sunulmuştur. Doğrusal, Kuadratik, Kübik, Gompertz, Lojistik ve Von Bertalanffy modelleri ile gerçekleștirilen analizler sonucunda hem Atak-S hem de Lohmann Brown tavuklarının haftalık yumurta ağırlıkları için en yüksek $\mathrm{R}^{2}$ (sırasıyla 0.9995 ve 0.9995 ) ve en düşük HKO değerleri (sırasıyla 2.0464 ve 2.4455) Gompertz modelinden elde edilmiştir. Her iki genotip için de doğrusal olmayan regresyon modelleri kullanılarak gerçekleștirilen analizlere ilişkin $\mathrm{R}^{2}$ değerleri eğri tahmin modellerinin $\mathrm{R}^{2}$ değerlerinden daha yüksek bulunmuştur. HKO değerleri bakımından değerlendirme yapıldı ğında ise Gompertz modeline en yakın değerler (ikinci en düşük) Atak-S için Y=$3.3214+3.6341 \mathrm{t}-0.0648 \mathrm{t}^{2}+0.0004 \mathrm{t}^{3}$ fonksiyonuyla elde edilirken, Lohmann Brown genotipi için Y=$39.7714+6.2286 \mathrm{t}-0.11819 \mathrm{t}^{2}+0.0007 \mathrm{t}^{3} \quad$ eşitliği kullanılarak sağlanmıştır. Atak-S ve Lohmann Brown hibritlerinin haftalara göre yumurta ağırlıklarının farklı modellerle tahmin edilmesiyle elde edilen tahmin grafikleri sırasıyla Şekil 2 ve Şekil 3'te sunulmuştur.

\section{Tartışma ve Sonuç}

Çalışmada Atak-S ve Lohmann Brown genotipleri için 24-80 haftalar arasındaki yumurta ağırlık ortalamaları bakımından istatistiksel farklılık bulunmamış olması ülke tavukçuluğu açısından sevindirici bir bulgudur. Fathel ve Elibol (2006) tarafından gerçekleştirilen bir çalışmada Ankara Tavukçuluk Araştırma Enstitüsü'nde geliştirilen Atak ve Atak-S genotipleri ile iki dış kaynaklı kahverengi yumurtacı hibrit (Nick Brown, Lohmann Brown) verim özellikleri bakımından karşılaştırılmıştır.

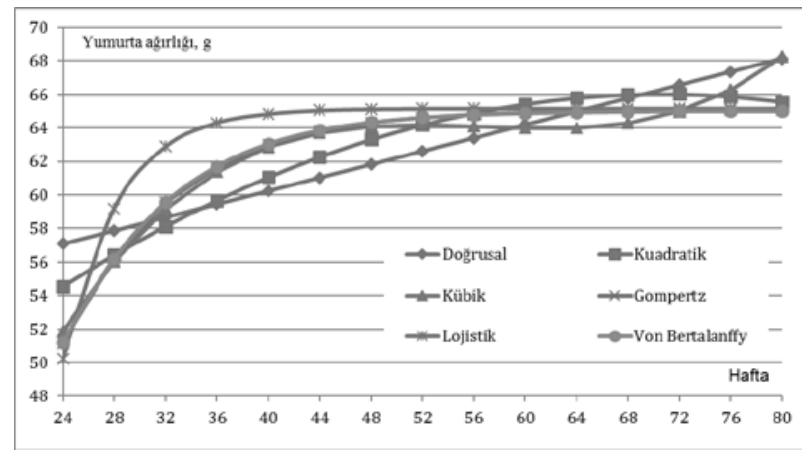

Şekil 2. Atak-S hibritlerinin haftalara göre yumurta ağırlıklarının farklı modellerle tahmin edilmesi.

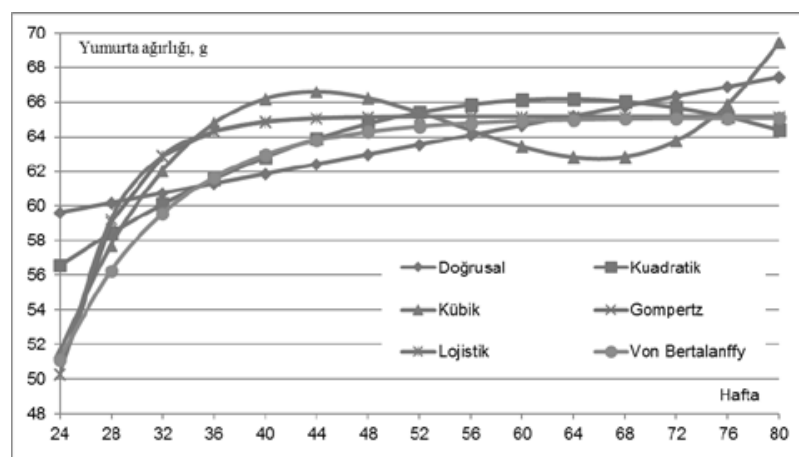

Şekil 3. Lohmann Brown hibritlerinin haftalara göre yumurta ağırlıklarının farklı modellerle tahmin edilmesi. 
Atak-S genotipinin 24, 31, 36, 42, 47, 53, 58, 65, 72 haftalık yaşlarda ölçülen yumurta ağırlık ortalamaları sirasıyla 56.86, 60.45, 61.10, 60.22, $60.22,60.87,62.45,64.13$ ve 65.79 g olarak bulunmuştur. Söz konusu çalışmada yumurta ağırlığının zamana bağlı değişimi için genotiplerin karşılaştırılmasında çok değişkenli istatistiksel yöntemler ya da zaman serisi gibi uzman istatistikler kullanılmamış olup, her bir zaman noktası için varyans analizleri yapılmıștır.

Çizelge 3. Yumurta ağırlıklarının zamana bağlı değişiminin modellenmesi amacıyla kullanılan fonksiyonlara ait parametre tahminleri ve uyum iyiliği kriterleri

\begin{tabular}{|c|c|c|c|c|c|c|}
\hline & Sabit & $\beta_{0}$ & $\beta_{1}$ & $\beta_{2}$ & $\mathrm{R}^{2}$ & $\mathrm{HKO}$ \\
\hline \multicolumn{7}{|c|}{ Atak-S } \\
\hline Doğrusal & 52.3674 & 0.1876 & - & - & 0.6690 & 6.6287 \\
\hline Kuadratik & 39.6935 & 3.0925 & -2.2995 & - & 0.7813 & 4.7377 \\
\hline Kübik & -3.3214 & 3.6341 & -0.0648 & 0.0004 & 0.9125 & 2.0677 \\
\hline Gompertz & - & 65.0802 & 4.7952 & 0.1254 & 0.9995 & 2.0464 \\
\hline Lojistik & - & 65.1641 & 100.1031 & 0.2482 & 0.9989 & 5.5334 \\
\hline Von Bertalanffy & - & 65.0243 & 6.8142 & 0.1353 & 0.9995 & 2.5190 \\
\hline \multicolumn{7}{|c|}{ Lohmann Brown } \\
\hline Doğrusal & 56.2627 & 0.1397 & - & - & 0.3015 & 15.5856 \\
\hline Kuadratik & 41.1606 & 0.7927 & -0.00628 & - & 0.4450 & 13.4151 \\
\hline Kübik & -39.7714 & 6.2286 & -0.11819 & 0.0007 & 0.8613 & 3.6580 \\
\hline Gompertz & - & 65.1003 & 1.4252 & 0.1212 & 0.9995 & 2.4455 \\
\hline Lojistik & - & 65.1612 & 163.3261 & 0.2632 & 0.9989 & 5.5070 \\
\hline Von Bertalanffy & - & 65.1654 & 28.4624 & 0.2433 & 0.9989 & 5.5431 \\
\hline
\end{tabular}

Fathel ve Elibol (2006) tarafından gerçekleștirilen çalışmada Atak-S genotipi ile yabancı ticari genotiplerin haftalık yumurta ağırlık ortalamaları çoğu zaman noktasında benzer bulunmuş olup, Atak$\mathrm{S}$ genotipine ilişkin ortalamaların diğer genotiplerden zaman noktasında daha düşük olduğu bildirilmiş olup çalışma bulgularıyla uyumlu olduğu söylenebilir. Benzer bir çalışmada dış kaynaklı Supernick ve Brownnick ticari yumurtacı sürüler ile yerli Atak, Atak-S ve Atabey genotiplerinin yumurta ağırlıklarını karşılaştıran Sarıca ve ark. (2010), Atak$\mathrm{S}$ genotipinin ortalama yumurta ağırlığının $65.21 \mathrm{~g}$ olduğunu ve Supernick genotipinden daha hafif yumurta ağırlı̆̆ına sahip olduğunu, buna karşllık Brownnick genotipinin yumurta ağırlığına benzer ortalamaya sahip olduğunu bildirmişlerdir. Söz konusu çalışmada yumurta ağırlı ortalamaları bakımından yerli Atak ve Atabey genotipleri yabancı muadillerinden daha düşük ortalamalara sahip olmuşlardır. Kamanlı ve ark. (2016) tarafından Tavukçuluk Araştırma Enstitüsü'nde bulunan HTBLC, HTBRV ve YTDLY kodları verilen ebeveyn hatlarından HTBLC*YTDLY ve HTBRV*YTDLY melezleri elde edilerek gerçekleştirilen bir çalışmada söz konusu melezlerin ortalama yumurta ağırlıklarının sırasıyla $61.37 \mathrm{~g}$ ve $62.68 \mathrm{~g}$ olduğu belirlenmiştir. Araştırıcılar araştırmada kullanılan melezlerin yumurta ağırlıklarının Lohmann Brown'dan düşük olduğunu bildirmişlerdir.
Lohmann Brown genotipi için yayımlanmış olan katalogda ise 30., 39., 64. ve 90. haftalara ilişkin yumurta ağırlık ortalamalarının sirasıyla 60.0, 63.0, 66.0 ve 66.6 g olduğu bildirilmiştir (Anonim, 2016).

Söz konusu değerler bu çalışmada hem Atak-S hem de Lohmann Brown genotipi için elde edilen benzer hafta ortalamalarıyla uyumlu bulunmuştur. Abiola ve ark. (2008) ve Wolc ve ark. (2012) tarafindan damızlık ve ticari yumurtacı sürülerde yumurta ağırlı̆ı̆ında ve dolayısıyla boyutlarındaki varyasyonun ne gibi olumsuz sonuçlar doğurduğu detaylı olarak açılanmıştır. Kullanılan her iki genotipe ait haftalık yumurta ağırlıklarındaki bir örnekliliğin göstergesi olan varyasyon katsayıları (\%) incelendiğinde Atak-S için saptanan değerlerin daha düşük ve daha dar bir aralıkta olduğu (\%5.23\%8.59), buna karşıllk Lohmann Brown genotipine ait değerlerin hem daha yüksek hem de daha geniş bir aralıkta olduğu (\%4.16-\%9.80) belirlenmiștir.

Matematiksel modeller, olayları ideal ve soyut olarak ele alıp yansız sonuçlara ulaşmayı sağlamaktadır. Örnekten toplanan verilerin ana kütle ya da sistemin bütünü bakımından değerlendirilebilmesi, işlenmesi, saptanan bulgulara açıklık kazandırılabilmesi, geniş ölçülerde geçerli hale getirilmesi ve sonraki durumlar için elde edilecek kestirimler matematiksel fonksiyonların kullanılmasıyla daha doğru ve anlamlı olmaktadır. 
Hayvancılı alanında toplanan verilerin modellenmesi amacıyla çok sayıda ampirik ve mekanistik modeller geliştirilmiş olup, bunların çoğu büyüme, süt verimi ve yumurta verimi ile ilgili olmuştur (Narinç ve ark., 2014b; Narinç ve ark., 2017).

Literatürde daha önce yumurta ağırlığının zamana bağlı değişiminin modellenmesi ile ilgili herhangi bir öğe bulunmamıştır. Bu çalışmada üç ampirik model (doğrusal, kuadratik, kübik) ve üç mekanistik model (Gompertz, Logistic, Von Bertalanffy) kullanılmıştır. Bulgular incelendiğinde her iki genotip için de yumurta ağırlığının zamana bağlı değișiminde uyum iyiliği kriterleri bakımından mekanistik modellerin ampirik modellere göre daha üstün olduğu, bunların içinde de en iyi sonuçların Gompertz modeli ile elde edildiği belirlenmiştir.

Söz konusu bulgular Ricklefs (1985) tarafından öne sürülen "biyolojik bir sistemde temel model ortaya konulursa, modelin parametreleri değiştirilerek ya da dönüştürülerek farklı koşullardaki benzer problemlerin çözülmesi sağlanabilir" görüşüne uyumlu bulunmaktadır. Bunun yanında Gompertz modeli, tahmini uzak asimptotik ağırlığın \% 37'sine tekabül eden zaman noktasında bükülme gösteren sigmoid yapıda bir fonksiyondur.

$\mathrm{Bu}$ tip sigmoid modeller bükülme noktasına kadar artarak artan, sonrasında ise azalarak artan bir değişkeni tanımlamak için kurgulanmıştır. Oysa yumurta ağırlığının zamana bağlı değişiminde bükülme noktası yaşı ya da ağırlığı hem biyolojik hem de bilimsel bir anlam taşımamaktadır. Yumurta ağırlığı zamana bağlı olarak sürekli artarak artan bir yönelim sergilemektedir ve sigmoid modeller ile açıklanması zordur. Bu nedenle yumurta ağırlığının zamana bağlı değişiminin biyolojik anlam taşıyan parametrelere sahip mekanistik modeller ile açıklanması konusunda daha fazla çalışma yapılmasına ihtiyaç vardır.

Yerli hibrit Atak-S ve yabancı hibrit Lohmann Brown sürülerinde 24-80 haftalar arasında dörder haftalık olarak ölçülen yumurta ağırlıkları bakımından iki genotip arasında farklılık bulunmamış olması, aynı zamanda yumurta ağırlığındaki bir örneklilik bakımından Atak-S genotipinin daha iyi sonuçlar vermiş olması ülke ekonomisi açısından önemli bulunmuştur. Zira yerli yumurtacl hibritlerimizin pazar payını arttırabilmesi ile önemli döviz kaybının önüne geçilebilecektir. Bunun yanında yumurta ağırlığının zamana bağlı modellenmesi konusunda da çalışmalar yapılması gerekmektedir.

\section{Kaynaklar}

Abiola, S. S., Meshioye, O. O., Oyerinde, B. O., Bamgbose, M. A., 2008. Effect of egg size on hatchability of broiler chicks. Archivos de Zootecnia, 57: 83-86.

Anonim, 2014. https://www.oecd.org/edu/Education-ata-Glance-2014.pdf (Erişim tarihi: 2 Ekim 2017).

Anonim, 2016. Lohmann Brown teknik el kitabı. Hastavuk, Bursa.

Aydın, D., Rashid, S. M., Aydın, R., 2014. Tavuk yumurtası ve kolesterol gerçeği. KSÜ Doğa Bilimleri Dergisi, 17(3): 26-29.

Davis, C. S., 2002. Statistical methods for the analysis of repeated measurements. Vol. 4: Normal-Theory Methods: Multivariate Analysis of Variance. Springer-Verlag, New York, NY.

Erensayın, C., 2000. Bilimsel-Teknik-Pratik Tavukçuluk (Yumurta Tavukçuluğu). Nobel Yayın Dağıtım Ltd. Şti, Ankara, Cilt:2, Yayın No:184, 472s.

Eyduran, E., Karakus, K., Keskin, S., Cengiz, F., 2008. Determination of factors influencing birth weight using regression tree (RT) method. Journal of Applied Animal Resources, 34:109-112.

Fathel, A. N., Elibol, O., 2006. Yerli ve Dış Kaynaklı Kahverengi Yumurtacı Hibritlerin Verim Özellikleri Bakımından Karşılaştırılması. Ankara Üniversitesi Ziraat Fakültesi Tarım Bilimleri Dergisi, 12(2): 182187.

Förster, A., Flock, D. K. 1997. Scope for further improvement of shell color in brown-egg type layers. Lohmann Information, 20: 19-22.

Kamanlı, S., Boğa, A. G., Durmuş, İ., 2016. Beyaz Yumurtacı Ebeveyn Hatlarında İkili Melez Kombinasyonların Bazı Verim ve Yumurta Kalite Özellikleri Bakımından Karşılaştırılması. Tavukçuluk Araştırma Dergisi, 13(1): 1-4.

Karakaya E, İnci H, Sögüt, B., Şengül, T., (2014). Bingöl il merkezinde yaşayan hane halklarının yumurta tüketim durumu üzerine bir araştırma. Türk Tarım ve Doğa Bilimleri Dergisi 1(2): 239-247.

Mendeş, M., Dinçer, E., Arslan, E., 2007. Profile Analysis and Growth Curve for Body Mass Index of Broiler Chickens Reared Under Different Feed Restrictions in Early Age. Archıv für Tierzucht-Archives of Animal Breeding. 50(4): 403-411.

Narinc, D., Karaman, E., Firat, M. Z., Aksoy, T., 2010/a. Comparison of non- linear growth models to describe the growth in Japanese Quail. Journal of Animal and Veterinary Advances, 9: 1961-1966.

Narinc, D., Aksoy, T., Karaman, E., 2010/b. Genetic parameters of growth curve parameters and 
weekly body weights in Japanese quail. Journal of Animal and Veterinary Advances, 9: 501-507.

Narinç D., Üçkardeş, F., Aslan, E., 2014/b. Egg production curve analyses in poultry science, World's Poultry Science Journal, 70: 817-828.

Narinç, D., Öksüz Narinç, N., Aygün, A., 2017. Growth curve analyses in poultry science, World's Poultry Science Journal, 73 (2): 395-408.

Ohaegbulem, E. U., Nwobi, F. N., 2009. Poultry feed brands selection using Profile analysis. Journal of Applied Sciences, 9 (7): 1368-1372.

Pingel, H., Jeroch, H., 1997. Egg quality as influenced by genetic, management and nutritional factors. Proceedings of VII European Symposium on the
Quality of Eggs and Egg Products. September, 2126, Poznan-Poland, pp.13-27.

Ricklefs, R. E., 1985. Modification of growth and development of muscles of poultry. Poultry Science, 64: 1563-1576.

Sarıca, M., Yamak, U. S., Boz., M. A., 2010. Dıș kaynaklı ve yerli yumurtacı hibritlerde yumurta kalitesinin yaşa bağlı değişimi. Tavukçuluk Araştırma Dergisi, 9 (1): 11-17.

Wolc, A., Arango, J., Settar, P., Fulton, J. E., O'Sullivan, N. P., Preisinger, R., Habier, D., Fernando, R., Garrick, D. J., Hill, W. G., Dekkers. J. C., 2012. Genome-wide association analysis and genetic architecture of egg weight and egg uniformity in layer chickens. Animal Genetics, 43: 87-96. 